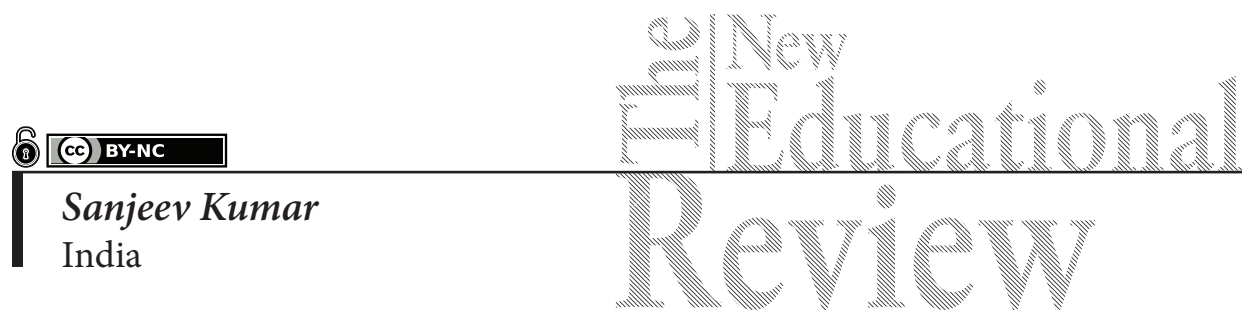

\title{
Professional Preparation of In-Service Teachers for 'Prayas' Program in Science and Impact in Classrooms
}

DOI: 10.15804/tner.2018.52.2.19

\begin{abstract}
Today most teachers enter teaching by means of a one or two-year undergraduate program in education (B.Ed.). There is provision of in-service training for teachers to make teaching effective in bringing quality to education. Various in-service teacher training programs are organized by District Institutes of Educational Training and State Institute of Educational Management and Training under Sarva Shiksha Abhiyaan in Himachal Pradesh. Yet, the impact of the training has not been reflected in the classrooms for the last fifteen years. There is not optimum improvement in the academic achievement of students. It is necessary to make teaching enjoyable and flexible through various activities, small projects and ICT in the new era. Creative and experimental activities are very much needed in the teaching of mathematics and science subjects. These activities help in building student confidence and give students more opportunities of learning. 'PRAYAS' at the upper-primary level is one of the programs organized by the DIET Solan to professionally prepare in-service teachers for implementing it at the school level. The objective of the study was to study the impact of the 'PRAYAS' in-service training program in Science in the educational block Kandaghat block of district Solan of Himachal Pradesh. Three schools were conveniently selected, two Govt. Senior Secondary Schools Chail and Kalhog, and one Govt. High School, Sakori, of the concerned educational block. Data was collected with the use of a semi-structured interview and the observations were recorded. It was found in the study that students made models and activities on the topics of their textbooks under the 'PRAYAS' program with eco-friendly materials and waste materials, utilized where suited.
\end{abstract}


In this way, students learnt to use waste materials in everyday life. The models and activities were very low cost and easy to handle and care. The students learnt and understood the concepts easily. The outcomes of the program are discussed in the paper, which will be beneficial for the educational planners and administrators and in-service teachers of the State.

Keywords: PRAYAS, science, in-service teachers, DIET, SSA.

\section{Introduction}

Today most teachers enter the teaching profession by means of a one or twoyear undergraduate program in education (B.Ed.). There is provision of in-service training for teachers to make teaching effective in bringing quality to education. Various in-service teacher training programs are organized by District Institutes of Educational Training and State Institute of Educational Management and Training under Sarva Shiksha Abhiyaan in Himachal Pradesh. However, the impact of the training has not been reflected in the classroom for the last fifteen years. There is not optimum improvement in students' academic achievement. It is necessary to make teaching enjoyable and flexible through various activities, small projects and ICT in the new era. Creative and experimental activities are very much needed in the teaching of mathematics and science subjects. These activities help in building student confidence and give students more opportunities of learning. PRAYAS at the upper-primary level is one of the programs organized by the DIET Solan to professionally prepare in-service teachers for implementing it at the school level.

\section{History of the Program (PRAYAS)}

DIET Solan launched the 'Sunehra Kal' program in one educational block, Ramshehar, in 2014, in which activities and models were constructed for maths and science content in primary and upper-primary school with the collaboration of the Praptham Education Foundation. Science and Maths fairs were organized to demonstrate these activities, in which students' parents and the local public also participated, along with teachers and students. A Science fair was organized on a large scale on 28/02/2015 at Govt. Senior Secondary School, Baddi. Students demonstrated mathematical activities and science models in front of administrators, teachers, students and the local public. They were praised for their work and self-confidence. 
The DIET Solan organized a five-day workshop, 'Making Maths Activities and Science Models', in Government (Boys) Senior Secondary School, Solan, in March, 2015, in collaboration with the Pratham Education Foundation for increasing the publicity of science fairs. 120 students of the school participated in this workshop and made various mathematical activities and science models (working and non-working). The $6^{\text {th }}$ to $8^{\text {th }}$ grade students made 30 science models and 20 mathematical models in this workshop and displayed them on the sixth day of the fair. The teachers and head teachers of the adjoining schools were also invited to participate in the fair. Taking into consideration the success of this fair, DIET decided to prepare three in-service teachers from each educational block through in-service teacher training program on 'Activity based Teaching' and prepared a District Resource Group (DRG) in April, 2015. All the science and maths teachers from Arki and Dhundan educational blocks were trained for this program and fairs were organized. The Pratham Education Foundation shared these experiences and program in Bilaspur district and DIET Bilaspur (Jukhala) converted it into 'PRAYAS' and implemented it in the whole district. Then, DIET Sirmour (Nahan) launched this program in two educational blocks. This program produced positive results and was popularized in the State. The State Project Office, Shimla, implemented this successful program in the State this year at the upper-primary level ( $6^{\text {th }}$ to $8^{\text {th }}$ grades).

\section{Review of Related Studies}

The review of the related studies helped the researcher to find a gap among the studies in the selected area. Sim, Ju Youn (2011) studied the impact of an in-service teacher training (INSET) course in Korea on teachers' classroom practice and their perception change. The main finding in this study indicated that the two examined teachers faced some difficulties and challenges in implementing new ideas or knowledge obtained from the INSET course into their classroom practice, and did not do so to the same extent. The contextual differences between the INSET and real practice, the content of the INSET, and lack of school support were identified as constraining factors that limit implementation. Uysal, H.H. (2012) studied evaluation of an in-service training program for primary school language teachers in Turkey. The study evaluated a one-week INSET offered by the Turkish Ministry of Education to explore its sustained impact on language teachers' attitudes, knowledge-base, and classroom practices. The program was first evaluated against the criteria for effective INSETs suggested by previous liter- 
ature. Then, data were gathered through course material analysis, interviews with trainers and teachers, and through a questionnaire distributed to 72 teachers, 18 months after the course had ended. Findings indicated that although the teachers' attitudes towards the course were positive in general, the program had limitations especially in terms of its planning and evaluation phases, and its impact on teachers' practices. However, teachers expressed a need for more time and resources such as handouts, materials, CDs to be used for future reference and for classroom use. Berry, Daughtrey and Wieder (2010) suggested that preparation and professional development are closely interwoven with collaboration and leadership opportunities. Due to these connections, the best proposals for creating and supporting professional learning for effective teachers will incorporate elements of each. Feiman-Nemser focuses on different ways of conceiving and carrying out teacher preparation. He discusses the state of the art of programs of initial teacher preparation and indicates where conceptual, empirical and practical work is needed. The academic orientation focused attention on the distinctive work of teaching. What distinguished teaching from other forms of human service is its focus on helping students learn worthwhile things they could not pick up on their own. What follows is that preparing someone to teach means helping them develop ideas and dispositions related to this goal. These studies provided insights into in-service teacher training and governments' initiatives in various places around the globe. The studies also investigated the aspects teachers found easy/ hard to implement, their reasons for any difficulties they faced in their schools, and their needs for future in-service teacher education programs. Because any changes in teachers' beliefs, attitudes and behaviors are considered to take place after a long period of time, once teachers have an opportunity to test new ideas and observe the outcomes in student learning. Hence, the present study was undertaken to study the professional preparation of in-service teachers for the 'PRAYAS' program and its impact in classrooms in Kandaghat block of district Solan of Himachal Pradesh.

\section{Objectives of the Study}

1. To study the professional preparation of in-service teachers for the 'PRAYAS' program in the educational block Kandaghat.

2. To study the impact of the 'PRAYAS' in-service training program in the science subject in the educational block Kandaghat. 


\section{Methodology}

A descriptive research method was used in the present study.

\section{Place of Study}

The present study was conducted in the educational block Kandaghat of the Solan district of Himachal Pradesh, India.

\section{Duration of the Study}

Four months: 05/09/2017 to 04/12/2017

\section{Type of Study}

School and community based qualitative study.

\section{Sampling}

The study was carried out in one educational block, Kandaghat of district Solan. There are 51 upper-primary schools in the block, from which 12 schools were selected by the DIET Solan for the 'PRAYAS' program. The researcher selected three schools conveniently, two Govt. Senior Secondary Schools, Chail and Kalhog, and one Govt. High School, Sakori, of the educational block in question. Data was collected with the use of a semi-structured interview and observations were recorded. Six teachers, 10 students and 10 SMC members were selected conveniently for recording their views concerning the 'PRAYAS' program in science.

\section{Data Analysis}

The outcomes of the observations made were recorded categorically and interpreted as follows.

\section{Professional preparation of in-service teachers for the 'PRAYAS' program}

In Himachal Pradesh, science is taught by trained graduate teachers in medical high and senior secondary schools and by trained graduate teachers in non-medical middle schools. The related stream teachers were selected by the Block Resource Coordinator and five-day professional in-service teacher training was organized by the DIET Solan for science. On the first three days, inputs were given regarding making various activities and models (working and non-working) of the $6^{\text {th }}$ to $8^{\text {th }}$ - grade syllabus in collaboration with the Pratham Education Foundation. The 
follow-up of the program was conducted on the fourth day, and the following day a fair was organized at the DIET level to demonstrate the activities and models prepared by the participant teachers. This group was referred to as a District Resource Group (DRG).

This training was conducted by the DRG members for one day at the block level in science to the in-service teachers of the streams and selected schools in which the 'PRAYAS' program is implemented. The follow up was also conducted on the next day of the training. In the Kandaghat block, $\leq 10000 /-$ were given to 12 selected schools for science and maths kit under the 'PRAYAS' program and $\leq 2756$ /- were allotted for making charts/models/activities of the topics of their textbooks of science and mathematics to other middle and senior secondary schools of the block.

\section{Impact of the 'PRAYAS' in-service training program in science}

The trained teachers at the block level implemented the training in their schools. The normal school routine was not disturbed but the teachers implemented the 'PRAYAS' program in their normal classroom teaching. The students made charts, activities and models (working and non-working) for science. The date of the fair was announced by the BRCC Kandaghat. The schools organized a fair to display the activities and models in front of all the students of the school, teachers, School Management Committee (SMC) and community members. The students explained the details of their models and activities with great confidence. The SMC members also interacted with the students along with the science teachers of nearby schools. The BRCC Kandaghat Smt. Kiran Thakur also interacted with each student and asked about the details of the charts/models/activities. She commented, "The students are learning the basic concepts of science with the help of these activities. The concepts are clear to students as they are learning the concepts of their textbooks by doing the activities in question." The researcher studied the impact of the 'PRAYAS' in-service training program at the basic level with the help of a semi-structured interview scale and recorded the views of science teachers, students and School Management Committee members of the selected schools.

\section{Views of Science Teachers}

The science teachers' views were recorded by the investigator with the use of a semi-structured interview scale. The concept of making a model or activity 
has been given to the students by the teachers. The students mostly used waste material for making the models. One of the teachers said, "The students are taking interest in learning the concept for developing the model and I think that they have learnt the concept more deeply than in normal classroom learning." Another science teacher said, "The students amazed all of us with their active involvement in these activities and good results in FA 2 and FA 3 tests. I think this will be the best program for science learning at this stage. I appreciate it personally." The views of 10 selected science teachers are presented in Table 1.

Table 1. Science teachers' views about the 'PRAYAS' program in science

\begin{tabular}{clcc}
\hline Sr. No. & \multicolumn{1}{c}{ Statement } & Yes & No \\
\hline I & Is the 'PRAYAS' program in science useful to students? & 6 & 0 \\
\hline II & $\begin{array}{l}\text { Are the students participating actively in developing the model/chart/ } \\
\text { activity? }\end{array}$ & 5 & 1 \\
\hline III & $\begin{array}{l}\text { Is the program helpful in the thorough learning of the concepts for which } \\
\text { the model/chart/activity is developed? }\end{array}$ & 5 & 1 \\
\hline IV & Is a scientific attitude developed in the students? & 6 & 0 \\
\hline V & $\begin{array}{l}\text { Is the students' performance in unit tests better than before implementing } \\
\text { the program? }\end{array}$ & 5 & 1 \\
\hline
\end{tabular}

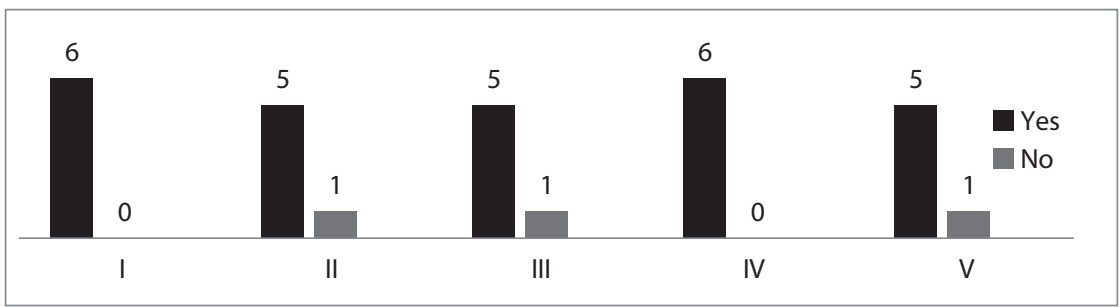

Figure 1. Views of Science Teachers towards 'PRAYAS' Program

Table 1 and Figure 1 show the science teachers' views concerning the 'PRAYAS' program in science. All the science teachers stated that it is useful for the students and scientific attitude is developed in the students, 5 teachers stated that the program is helpful in the thorough learning of the concepts for which the chart/ model/activity has been developed and all the students actively participated in doing the activities, and the students' performance in FA 2 and FA 3 tests was better than before implementing the program. 


\section{Students' Views}

The students' views concerning the implementation of the 'PRAYAS' program in science in schools were recorded with the use of a semi-structured interview scale. The students were found more interested in making charts/models in class with the help of their teachers. One student of the $6^{\text {th }}$ grade reported, "I was a slow student in science. The concepts were tough for me to understand, but, by making a chart/model with the help of the teacher I understood the things better and got good marks in FA 2 tests." Another student of the $8^{\text {th }}$ grade said, "I really enjoyed doing the activity myself as I read about it in my textbook. It boosted my confidence to do more in future." Vivek Sharma of grade 8 said, "I felt proud when teachers of other schools appreciated my model along with the skill of explaining how it worked. I am self-motivated and now I will do more activities of other topics of my syllabus. I have learnt the concept and I cannot forget it now." The recorded views of all the sample students are shown in Table 2.

Table 2. Students' views about the 'PRAYAS' program in science

\begin{tabular}{llcc}
\hline Sr. No. & \multicolumn{1}{c}{ Statement } & Yes & No \\
\hline I & Did you get guidance from your teachers in making the chart/model? & 10 & 00 \\
\hline II & $\begin{array}{l}\text { Have you learnt the concepts in-depth with the help of all charts/models } \\
\text { developed by the class? }\end{array}$ & 8 & 2 \\
\hline III & $\begin{array}{l}\text { Have you got good marks in FA 2 and FA 3 tests after learning through } \\
\text { these activities? }\end{array}$ & 7 & 3 \\
\hline IV & Would you like to develop more charts/models for other concepts? & 8 & 2 \\
\hline V & Are you planning to develop charts/models for other concepts? & 6 & 4 \\
\hline
\end{tabular}

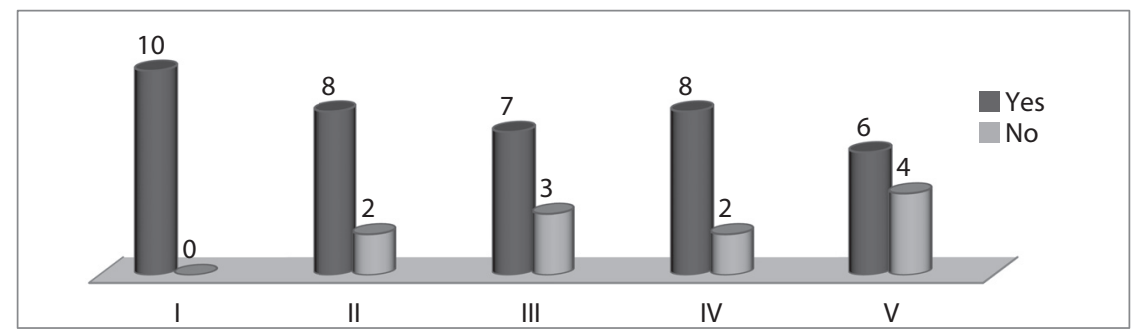

Figure 2. Students' Views towards 'PRAYAS' Program in Science

Table 2 and Figure 2 present the students' views about the 'PRAYAS' program in science. It is clear that all the students were guided by their respective teachers 
for developing the chart/model/activity in science. 8 students stated that they had learnt the concepts of their syllabus books easily and in-depth with the help of the material developed in the program and got good marks in FA 2 and FA 3 tests. 8 students would like to make more materials of other concepts of science in future and 6 students planned their strategies for making their project during the program. The remaining 4 students were also planning to make their activities of the topic of their interest related to the syllabus.

\section{Views of School Management Committee (SMC) Members}

The students' views about the implementation of the 'PRAYAS' program in school were recorded through a semi-structured interview scale. The SMC President of one school said, "The PRAYAS' program is the best program to create the interest of the students towards science. The children are enjoying their learning by creating things themselves." The parent of a student stated, "The students are taking a keen interest in making their models. They are learning the basic concepts more easily and I think this learning is permanent." The views of all the SMC members are presented in Table 3.

Table 3. SMC Members' views of the 'PRAYAS' program in science

\begin{tabular}{|clll|}
\hline Sr. No. & \multicolumn{1}{c}{ Statement } & Yes & No \\
\hline I & Did you like the work done by the students? & 10 & 00 \\
\hline II & Did your children make these charts/models with interest? & 7 & 3 \\
\hline III & Did the children need money for making these activities? & 1 & 9 \\
\hline IV & Do you think such a type of activities and fairs should be continued in future? & 10 & 00 \\
\hline V & Did the performance of your children increase during this program? & 8 & 2 \\
\hline
\end{tabular}

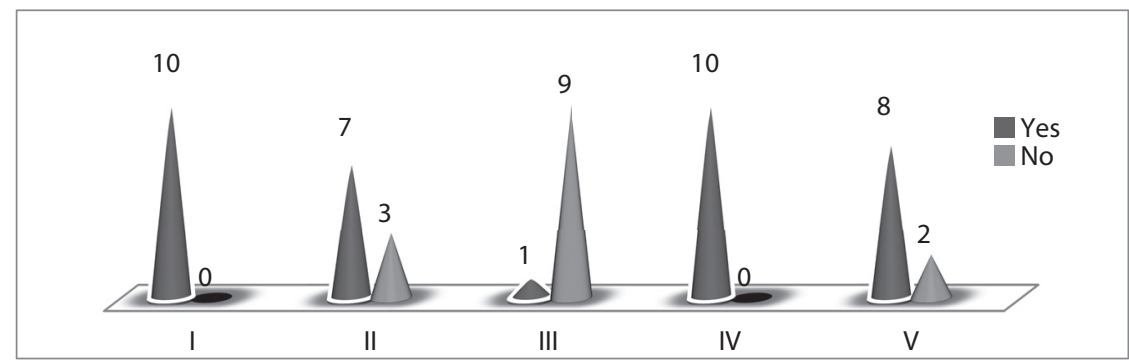

Figure 3. View of School management Committee Members towards 'PRAYAS' Program in Science 
Table 3 and Figure 3 show the views of the School Management Committee members concerning the 'PRAYAS' program. All the SMC members liked the students' work and planned this type of activities in future. 7 members made their charts/models with interest and 8 members were of the opinion that the performance of their children in science increased due to the implementation of this program.

\section{Conclusion}

Science is a subject which should be taught by activity-based methods. This type of activities help students to understand the concept easily and discourage rote learning. The students made their models using eco-friendly material and waste material was also utilized where suited. In this way, the students learnt to use the waste material of everyday life. They were low cost models and activities and easy to handle and care for. This is the outcome of the professional preparation of the 'PRAYAS' in-service teacher training program. The SMC members and community members appreciated the program and wanted to implement it in all the remaining schools of the block. It is concluded that the 'PRAYAS' program for science is successful in all the selected schools as BRCC Kandaghat reported. The students learnt the basic concepts of the syllabus of their textbooks very easily, which was proved by their results in FA 2 and FA 3 tests. The science subject should be taught with the students' active participation to increase their interest in the subject.

\section{Recommendations}

1. The 'PRAYAS' program was found useful for the students in the practical subject 'Science.' The students' performance was increased after the implementation of the program. Hence, the program should be implemented in other schools, as well.

2. The grant $\leq 2840$ is not enough for making the models in one school. It should be enhanced up to $\leq 4000$ for each school.

3. No program is successful without the active participation of the community. Therefore, SMC members should encourage their children for making more models/charts/activities.

4. Science teachers should be trained at the national level to make the program more effective and fruitful. 


\section{References:}

Berry, B., Daughtrey, A. and Wieder, A. (2010). Preparing to Lead an Effective Classroom: The Role of Teacher Training and Professional Development Programs. Center for Teaching Quality and Teachers Network. Hillsborough, NC: National Commission on Teaching and America's Future, USA.

Feiman-Nemser, S. Teacher Preparation: Structural and Conceptual Alternatives. In W.R. Houston (ed.), Handbook for Research on Teacher Education (New York: Macmillan).

Sim, Ju Youn (2011). The impact of in-service teacher training: a case study of teachers' classroom practice and perception change. Other thesis, University of Warwick. Retrieved from http://wrap.warwick.ac.uk/36858/ on 25/09/2016.

Uysal, H.H. (2012). Evaluation of an In-service Training Program for Primary-school Language Teachers in Turkey. Australian Journal of Teacher Education, (37)7. Retrieved from http://www.ro.ecu.edu.au/ajte/vol37/iss7/2 on 25/09/2016. 